\title{
Jak się ukryć za słowami? \\ Tomasz Lukasz Nowak, Język ukrycia. Zapisany \\ socjolekt gejów, Universitas, Kraków 2020, ss. 273
}

Rdzeniem każdego socjolektu jest słownik, to on bowiem decyduje o sposobie opisywania świata $\mathrm{w}$ jego możliwie pełnym kształcie, oddawania zjawisk i relacji w nim zachodzących, przedstawiania sfer postrzeganych zmysłowo i odbieranych intelektem, w tym także wyrażania się o samym języku. Dlatego nie ma dwóch takich samych języków, bo nie ma dwóch takich samych (na poziomie wspólnotowym i jednostkowym) wrażliwości, dwóch takich samych perspektyw i doświadczeń. Socjolekt jako język grupy $-\mathrm{z}$ jednej strony pozwala się grupie scalić poprzez możliwość identyfikowania się z określonymi wartościami i wyrażania stosunku do rzeczywistości, pozwala na odróżnienie się pozostałych poprzez sygnalizowanie odrębności, wreszcie pozwala zakreślić granice tego wszystkiego, co dla członków grupy ważne i znaczące; z drugiej strony - właściwości socjolektu decydują o postrzeganiu grupy, jej ciągłości, zmienności, roli, miejscu w pejzażu społecznym.

Tylko pozornie pierwsza perspektywa ma charakter wewnętrzny, jest spojrzeniem od środka, a druga mogłaby uchodzić za ogląd zewnętrzny. Rzecz jasna ta dwoistość ma przełożenie na obserwowane zjawiska - raz są to bowiem składniki języka tożsamościotwórcze, raz - społeczne (socjalne). Mówiąc o socjolekcie, badacz zawsze mierzy się z tymi perspektywami: socjolekt zawsze bowiem wymaga tła, tworzy się w obrębie jakiejś makrowspólnoty. Ten społeczny kontekst jawi się jako punkt odniesienia, prowadząc do poszukiwania odpowiedzi na pytanie, po co socjolekt się utworzył, jakie potrzeby komunikacyjne zaspokaja, jakie zakresy tematyczne obsługuje, czym - wreszcie - różni się od języka ogólnego.

Lektura Języka ukrycia. Zapisanego socjolektu gejów Tomasza Łukasza Nowaka prowadzi czytelnika po terytorium w humanistyce współczesnej silnie eksplorowanym, wiążącym się z mniejszościami seksualnymi, które opisywane są w monografii w kontekście komunikacyjnym. W towarzyszącym autorowi pojęciu językowego obrazu świata, kotwiczącemu takie składniki, 
jak konceptualizacje i kategoryzacje rzeczywistości pozajęzykowej, język jest traktowany jak klucz, otwierający przestrzenie związane z potrzebami wypracowania i używania socjolektu. Metodologia związana z odtwarzaniem językowego obrazu świata łączy komunikację z kulturą, a właściwie wskazuje, że są to dwie współzależne, współkonstytuujące się sfery.

Publikacja podzielona jest na dwie części - pierwsza ma charakter referujący i deklaratywny, druga - analityczny. Aparaturę teoretyczną autor ustawia zgodnie z porządkiem właściwym etno- i socjolingwistyce, korzysta przy tym głównie z pojęcia odmiany socjalnej języka (socjolektu), którą definiuje, przywołując ustalenia badaczy klasycznych - Stanisława Grabiasa czy Ewy Kołodziejek, ale również późniejszych - Tomasza Piekota, Anny Niepytalskiej-Osieckiej, Barbary Pędzich. Katalog warunków zaistnienia socjolektu podpowiada autorowi Aleksander Wilkoń, a ku odnalezieniu miejsca w klasyfikacji odmian polszczyzny kierują m. in. Stanisław Urbańczyk, Danuta Buttler, Andrzej Markowski, Halina Satkiewicz. Autor dostrzega - podobnie jak wcześniejsi badacze - kłopoty klasyfikacyjne i definicyjne w obrębie typologii polszczyzny, ale właściwie nie wychodzi poza obszar, który wyznaczył sobie w tytule. Pomimo skupienia się na samym socjolekcie widzi trudności związane z względnością ustalanych podziałów (trudność ta polega przede wszystkim na tworzeniu poszczególnych klasyfikacji bez udziału faktycznego materiału językowego, bez realnie używanych komunikatów). Balansuje jednak pomiędzy różnymi ustaleniami, unikając przypisania się do konkretnego rozumienia, ani też nie tworzy żadnej skonkretyzowanej kombinacji na potrzeby własnych rozważań. Formułuje otwarte pytanie, którego zretoryzowany, przewrotny kształt ukrywa pułapkę; pyta autor, czy język nienormatywnej społeczności można podporządkować normalizacji. Widoczna rozbieżność przyporządkowania obu tych norm (normatywności czy normalizacji) budzi wątpliwości, gdyż sugeruje trop myślowy dość niefortunny, by nie powiedzieć - ryzykowny. Czy wobec takiego stawiania sprawy nie można ustalać dla „społeczności z (nie)normy” granic językowych cech i właściwości?

Bardzo ciekawą poznawczo częścią (może ona służyć jako samodzielny tekst polecany jako lektura wspomagająca dydaktykę) jest raport ze stanu badań nad socjolektami mniejszości (rozdział 2, część I). Nowak referuje liczne prace odnoszące się do relacji języka i seksualności/homoseksualności, w tym również, co warto podkreślić, własne opracowania. Dał się bowiem poznać już przed publikacją swojej monografii jako autor, którego przedmiotem badań były elementy świata związane z gejami i lesbijkami - małżeństwo, rodzina, przestrzeń, jak również zagadnienia nominacji osób homoseksualnych. Te pojedyncze artykuły sygnalizowały wiedzę i rozeznanie badacza, których potwier- 
dzeniem jest Język ukrycia... Języki mniejszości - dziś stanowiące materiał do wielu badań z zakresu nie tylko lingwistyki (w wymiarze socjo-, pragma-, psycho-, etnolingwistycznej), ale także literaturoznawstwa, socjologii, politologii, kulturoznawstwa czy antropologii - bardzo często są podstawą do oceny relacji wewnątrzgrupowych (np. w społeczeństwach, narodach), stopnia ich otwartości i aksjologii związanej z odmiennością. Inny (w tym inny język) może pełnić wiele funkcji (kulturowych, społecznych, politycznych, ideologicznych etc.), poprzez które jaskrawo uwidoczniają się granice emancypacji. Jerzy Kmita, analizując rortiańskie pojęcie ironii [Kmita 2004], zauważył, że im głośniej, energiczniej mówimy o obszarach naszej emancypacji, walczymy o poszerzenie jej granic, tym bardziej ograniczamy jej terytorium (kurczy się ono w wyniku tej walki). Emancypacja więc wymagałaby spokoju, namysłu, dystansu, a przede wszystkim roztropności (choć Kmita sugeruje, że mogłaby się w tej mitygującej roli sprawdzić ironia). Symboliczne interakcje wytwarzają, utrwalają i modyfikują znaczenia, jeśli więc Nowak przywołuje badania nad językiem mniejszości seksualnych i dalej - samą historię homoseksualności, działa na rzecz emancypacji w powściągliwy, a więc w bardzo użyteczny sposób.

Omawiając historię homoseksualności, autor ustala siatkę reprezentacji językowych, które odnoszą się do nienormatywnych seksualnie mężczyzn: urning - sodomita - homoseksualista - gej - przedstawiciel trzeciej płci pedat-ciota ${ }^{1}$. Oprócz tego relacja obejmuje historyczną zmienność ujmowania homoseksualności, którą traktowano bardzo różnorodnie; są to podejścia: neutralne, naturalne, akceptujące, wrogie, stygmatyzujące, wykluczające etc. Postawy te przejawiają się w traktowaniu homoseksualności jako zagadnienia medycznego, psychologicznego, społecznego, kryminalnego, kulturowego, prawnego. Te historyczne rozpoznania pokazują, jak bardzo nienormatywność seksualna jest niestabilna w ocenie i podejściu grup większościowych. Jeśli zastosować za Bożeną Witosz oś rozpiętą pomiędzy biegunem „dyskurs wykluczenia” a przeciwnym mu „dyskursem tolerancji”, widać, że język wykluczonych (tu: język ukrycia) nie ma stałego miejsca [Witosz 2010]. Wędruje po tej osi w zależności od okoliczności zewnętrznych (społecznych, ideologicznych, kulturowych etc.), bardzo rzadko zbliżając się do bieguna tolerancji.

Poszukując uzasadnienień dla swoich badań, Nowak kierował się - co istotne - motywacjami ściśle naukowymi (s. 43), a nie doraźnym zaangażowaniem w debatę publiczną dotyczącą społeczności mniejszościowych w odnie-

1 Określenia te tworzą siatkę, a nie zwykłą listę. Widoczne są bowiem powroty różnych nazw w historii, tworzą one swoiste pętle i spirale, które powstają w efekcie kulturowych, społecznych czy też politycznych okoliczności. 
sieniu do orientacji seksualnej. Zagadnienia te rozpoczynał badacz zapewne w czasach nieco bardziej politycznie zastygłych, bez tak bardzo rozognionego sporu, bez tak daleko posuniętych działań dyskryminacyjnych i wykluczających, z jakimi mamy współcześnie do czynienia w sferze publicznej.

Książka przynosi opracowanie zwarte i w całości odniesione do socjolektu, którego źródłem jest prasa - kilkanaście zinów i czasopism skierowanych do homoseksualnych mężczyzn. Co warto zaznaczyć, materiał obejmuje drugą połowę lat 80 . XX wieku, a zatem czas bezpośrednio przed transformacją polityczno-gospodarczą w Polsce (częściowo nawet już do niej równoległy), wyznaczaną takimi zmianami, jak: upadek komunizmu, rozwój wolnego rynku, otwarcie kulturowo-społeczne na standardy świata zachodniego. Trzeba docenić żmudne wynajdywanie źródeł, pieczołowite przejrzenie archiwów i doskonałą orientację w tym obszarze.

Ulokowanie źródła materiału w wydawnictwach drukowanych skutkuje jego ograniczeniem do form zapisanych, co sygnalizuje już podtytuł książki. Dlaczego to takie istotne? Należy podkreślić, że zawężenie badań socjolingwistycznych do form utrwalonych w piśmie ma długą tradycję, nie jest niczym niezwykłym, choć wypada zauważyć, że znacznie bardziej zróżnicowany korpus uzyskuje się w studiach nad językiem mówionym. Zakreślenie jednak takiego obszaru pozyskiwania leksyki socjolektalnej ma swoje niewątpliwe walory: można się przyjrzeć frekwencji i zakresowi użycia oraz łatwiej zrekonstruować pewną, wyczerpującą definicję, której powstanie uzasadniają konteksty.

Jednakże słownik utworzony ze zbioru reprezentacji (leksykalnych) odzwierciedlających rzeczywistość w języku staje się rodzajem niebezpiecznie ograniczającego narzędzia, bowiem gromadząc leksykę socjolektalną, zawęża widzenie świata tylko do tego wąskiego rejestru i pomija wiele sfer ważnych, wręcz kluczowych dla grupy. Ograniczenie to ma miejsce, gdyż wspomniane sfery obsługuje słownictwo niesocjolektalne, wspólnoodmianowe, a zatem należące do leksykonu języka ogólnego. Analiza ograniczona wyłącznie do leksykonu socjolektalnego może dawać mylne wrażenie, że ważne dla jego użytkowników są tylko te zakresy i pola leksykalno-semantyczne, które korzystają z tego słownika (tu: obszar seksualności jako źródła tożsamości). Tymczasem w kontekście omawiania wartości istotnych dla grupy, jej doświadczeń, przeżyć czy wyobrażeń niesie to ze sobą zbyt duże uproszczenia, a nawet zniekształcenia. Narzędzia lingwistyki kulturowej wskazującej na ścisłą relację pomiędzy językiem a rzeczywistością pozajęzykową pozwalają wszak ujawnić, jak język kształtuje myślenie o świecie i w konsekwencji - sam świat. 
Wydaje się, że każda próba opisu języka gejów odpowiada na ich potrzebę społecznego zaistnienia. Uwidocznienie się tej grupy w badaniach nad polszczyzną jest tym bardziej konieczne do zauważenia i docenienia, gdy w dyskursie medialnym społeczność ta przedstawiana jest wybiórczo, jednostronnie (strona zależy od medium), a przedstawienie to zawsze ciąży ku ideologizacji i staje się doraźnym argumentem w różnych dyskusjach. Aktualne uwidocznienie tej społeczności w dyskursie publicznym jest nieadekwatne i bardzo jednostronnie uproszczone, a w obecnej sytuacji kulturowej w Polsce społeczność ta, jej życie, obyczajowość i estetyka są przedstawiane w sposób podporządkowany bieżącym potrzebom argumentacyjnym w dyskursach ideologicznych (politycznych). Obraz ten jest zniekształcony, wyłania się z niego demoniczna, zagrażająca większości mniejszość.

Judith Butler uważa, że jeśli istnieje podmiot (np. kategoria mężczyzn nienormatywnych seksualnie), to w języku pojawia się dla niego reprezentacja, która następnie ma wpływ na umocowanie tego podmiotu w społeczeństwie, polityce, prawodawstwie etc. [Butler 2009]. Tym samym wskazuje na więź pomiędzy tożsamością, językiem i rzeczywistością [Edwards 2009: 20]. Jeśli podmiot pozostaje niewidoczny, ukrywa się, a w konsekwencji - skrywa język i językowe reprezentacje własnej tożsamości, to rodzi się pytanie o jego funkcjonowanie w świecie. Tytułowe ukrycie można skojarzyć z kategorią wyznaczaną często dla niektórych socjolektów, mianowicie z tajnością. Staje się ona siłą takiego kodu, gdyż chroni informacje, ogranicza dostęp i nakłada filtr na język, tak by pozostał niemożliwy do odkodowania przez nieuprawnionych. Kod udostępniony jest członkom grupy, której tożsamość wypływa z tego samego źródła. Czy jednak w przypadku monografii Nowaka tajność i ukrycie są synonimami? Ukrycie oznacza, że uprawnienie wymaga czegoś więcej niż zwykłej znajomości kodu, może się ono przenikać z budowaniem znaczenia pragmatycznego. Kiedy zwykłe dekodowanie zawodzi, uruchamiamy wnioskowanie inferencyjne, a zatem skupiamy się na elementach znaczeniowych umieszczonych nie tylko w wypowiedzi, ale także w jej otoczeniu - wnioskujemy z kontekstu, sensy powstają dzięki sile sytuacji komunikacyjnej i kontekstowi rozumianemu zarówno wąsko, jak i szeroko, nadawczo i odbiorczo, lokalnie i globalnie etc. Ma to duże znaczenie w przypadku prasy (nawet o ograniczonym zasięgu) w sposób oczywisty operującej jawnością. Ukryte pozostają więc nie same komunikaty, ale przede wszystkim tożsamość twórców tych przekazów.

W ogromnym uproszczeniu można stwierdzić, że w socjolekcie gejów świat zrekonstruowany przez Nowaka jest antropocentryczny, w centrum stoją mężczyźni nienormatywni seksualnie, a wokół obcy - o odmiennej seksualno- 
ści i z różnym nastawieniem. Życie dotyczy głównie seksualności i toczy się w przestrzeniach i czasie jej podporządkowanych (zob. s. 245). Analizy leksyki socjolektalnej są bardzo rzetelne, zniuansowane, czasami nawet subtelne. Autor dowodzi neutralności określeń ciota czy pedat, które uchodzą w polszczyźnie ogólnej za wulgarne lub obraźliwe, a w wielu innych przypadkach wynotowuje osobliwości stylistyczne czy słownikowe. Dostrzega liczne „markery gejowskie" - szyfry ulokowane w ubiorze, ozdobach, makijażu, w warstwie pozawerbalnej, mające metakomunikacyjne znaczenie, które to znaki pozwalają mu na trafniejsze rozpoznania sensów (w kontekście).

Na koniec chciałabym jeszcze zwrócić uwagę na drobniejsze, ale efektowne rozwiązania związane z samym wydaniem. Obudowa edytorska monografii Nowaka obejmuje motta otwierające i podsumowujące (to ciągle rzadkość w polskiej edycji tekstów naukowych). Swoje opracowanie autor rozpoczyna trzema cytatami odnoszącymi się do podstawowego rozróżnienia istotnego dla powstania socjolektów - dualizmu światów: własnego (a więc i zrozumiałego, i sensownego) oraz tego ,zewnętrznego”, w którym grupa musi się ukrywać (co samo w sobie jest perwersyjne). Co ciekawe, te same cytaty otrzymuje czytelnik na zakończenie lektury. Z jednej więc strony otwierają one sytuację odbioru, ustawiają czytelnika w odpowiedniej osi, ukierunkowują jego obcowanie z tekstem, z drugiej zaś - stanowią podsumowanie, kumulację treści. Ujęcie tekstu w klamrę nie jest więc bez znaczenia - początek jest tu momentem sugerowania postawy (nadawczej i odbiorczej jednocześnie), a koniec jej weryfikacją, swoistym „sprawdzam”.

Pozwolę sobie jeszcze na uwagę, która wykracza nieco poza zakres przewidziany dla artykułu recenzyjnego. Książka Nowaka jest tomem, który zasługuje na docenienie swej materialnej postaci, bo jest także przedmiotem niezwykle estetycznym, w którym nie ma przypadkowych elementów. Ilustracja na okładce (powtórzona jeszcze na stronie tytułowej) oraz na skrzydełku, przedstawiająca mężczyzn elegancko ubranych, w melonikach, wśród których ukrywa się jeden zarumieniony ze spuszczonym wzrokiem, jest wyraźnie spójna z tytułem publikacji. Doceniam!

Wykorzystanie przez Tomasza Łukasza Nowaka warsztatu socjolingwistycznego, co zwykle lingwistę wręcz obliguje do przyglądania się fenomenom językowym przez pryzmat rozszczepiający ów ogląd na wiele aspektów, przyniosło niezwykły efekt. Praca nie tylko zasługuje na uwagę świata naukowego, ale też otwiera się na szerszą publiczność, co należy podkreślić w odniesieniu do aktualnej sytuacji społeczno-politycznej. I oczywiście, co z całą mocą chcę podkreślić, nauka nie polega na zaangażowaniu w debatę publiczną, ale - gdy staje się jej częścią - może odegrać bezprecedensową rolę: uporządkować 
dyskurs, zintelektualizować jego przebieg, wzmocnić argumentację, wskazać nadużycia i pomóc w znoszeniu uprzedzeń. Chciałabym więc jednoznacznie polecić lekturę monografii Język ukrycia. Zapisany socjolekt gejów, która bez wątpienia zasługuje na uwagę badaczy języka oraz obserwatorów życia społecznego.

Monika Grzelka

\section{Bibliografia}

Butler Judith (2009), Podmioty ptci/gender/pragnienia, przeł. Michał Gusin, w: Język, dyskurs, społeczeństwo, red. Lotar Rasiński, Warszawa, s. 348-361.

Edwards John (2009), Language and Identity: Key Topics in Sociolinguistics, New York.

Kmita Jerzy (2004), Destrukcyjna epoché ironii, w: Powaga ironii, red. Agnieszka Doda, Toruń, s. 11-20.

Bożena Witosz (2010), O dyskursie wykluczenia i dyskursach wykluczonych z perspektywy lingwistycznej, ,Tekst i Dyskurs - Text und Diskurs”, nr 3, s. 9-25. 
